DoI: http://dx.doi.org/10.21784/ZC.2018.007

\title{
Prace komisji stałych rad miejskich na przykładzie Komisji Oświaty i Spraw Społecznych Rady Miejskiej w Miłomłynie (2014-2016)
}

\author{
Works of the permanent councils of municipal councils \\ on the example of the Committee for Education \\ and Social Affairs of the City Council in Miłomłyn
}

\section{Streszczenie:}

W niniejszym artykule przeanalizowano działalność Komisji Oświaty i Spraw Społecznych Rady Miejskiej w Miłomłynie w latach 2014-2016. Podstawowym źródłem wskazującym na zakres prac komisji oraz podejmowane decyzje są protokoły z posiedzeń komisji oraz uchwały, które stanowią o ewentualnym zakresie pracy, składzie komisji i innych wewnętrznych sprawach organu pomocniczego. Na podstawie materiałów źródłowych autor przedstawił sposób pracy komisji oraz najważniejsze wydarzenia związane z działalnością jej członków.

słowa kluczowe: komisje stałe rad miejskich, Miłomłyn

\begin{abstract}
:
The following publication has analyzed the operations of the Education and Social Committee of the city council in Miłomłyn between 2014-2016. The main source of information about the scope of the Committee work and the decisions made, are reports from Council's meetings as well as resolutions, which comprise a possible scope of work, the Committee member's list and details on other internal activities of the assisting authority. Based on reference data author has presented the way the Committee
\end{abstract}


Franciszek Brzozowski - Prace komisji stałych rad miejskich...

operates and an overview of the main events related to the work of the Committee Members.

keywords: permanent councils of municipal councils, Milomlyn,

\section{Wprowadzenie}

Celem niniejszego artykułu jest ukazanie trybu i efektów pracy komisji stałych na przykładzie Komisji Oświaty i Spraw Społecznych Rady Miejskiej w Miłomłynie. Przeanalizowane zostały protokoły z posiedzeń komisji oraz najistotniejsze dokumenty dotyczące zakresu działalności komisji stałych w polskim systemie prawnym.

Literatura dotycząca samorządu terytorialnego w Polsce ${ }^{1}$ jest dość obszerna, jednakże nie znajdziemy w niej wiele informacji dotyczących organów pomocniczych rady, jakimi są komisje - czy to stałe, czy doraźne. Autorzy omawiają przede wszystkim zakres prerogatyw, jakie otrzymują komisje. Zwraca się uwagę na ich zależność od rady gminy oraz istotną rolę komisji rewizyjnej w ustroju samorządowym² ${ }^{2}$. Niektóre publikacje ${ }^{3}$ szerzej omawiają kwestie członkostwa w komisji, co nie jest jednoznacznie wskazane w ustawie o samorządzie gminnym. Ta kwestia została dopełniona wyrokami Sądu Najwyższego, który wskazał, że rada winna ograniczać liczbę składu osobowego komisji ${ }^{4}$ o komentarz do składu osobowego komisji pokusił się w swojej publikacji Bogdan Dolnicki, który wskazał, że „komisje powinny być organami fachowymi, mającymi służyć radzie pomocą przy wykonywaniu zadań, na przykład przez opiniowanie projektów uchwał" ${ }^{\text {. S }}$ Skoro winny być

${ }^{1}$ Z. Bukowski, T. Jędrzejewski, P. Rączka, Ustrój samorządu terytorialnego, Toruń 2005; B. Dolnicki, Samorzq̨d terytorialny, Warszawa 2012; H. Izdebski, Samorząd terytorialny. Podstawy ustroju i działalności, Warszawa 2009; B. Kisiel (red.), Prawo terytorialne w Polsce, Warszawa 2006; A. J. Kozłowski, Samorząd terytorialny w Polsce, Szczecin 1997; E. J. Nowacka, Polski samorząd terytorialny, Warszawa 2006; S. Wójcik, Samorzqd terytorialny w Polsce w XX wieku, Lublin 1999.

${ }^{2}$ E. J. Nowacka, Polski samorzq̨d..., op. cit., s. 65; S. Wójcik, Samorzq̨d terytorialny..., op. cit., s. 306.

${ }^{3}$ Z. Bukowski, T. Jędrzejewski, P. Rączka, Ustrój samorzq̨du..., op. cit., s. 190-191.

${ }^{4}$ Wyrok SN - Izba Administracyjna, Pracy i Ubezpieczeń Społecznych z dnia 7 marca 1996 r., sygn. Akt II ARN 56/95, OSNAPiUS 1996 r., nr 18, poz. 257.

${ }^{5}$ B. Dolnicki, Samorzqd terytorialny..., op. cit., s. 80. 
organami fachowymi, to zapewne wskazane jest, aby w komisjach zasiadały osoby do tego przygotowane, zainteresowane tematyką posiedzeń oraz posiadające wiedzę w zakresie, który obejmuje dana komisja. W literaturze przedmiotu jest niewiele publikacji związanych z samorządem, które dokładnie opisują działalność komisji rady. Za główną przyczynę takiego stanu można winić wagę omawianego problemu dla całego procesu samorządności, specyfikę pracy komisji oraz uregulowania prawne, które determinują ich działalność. Właśnie kwestie prawne są w dużej mierze przedmiotem dyskursu o samorządności na szczeblu komisji.

\section{Uwarunkowania prawne}

Artykuł 21, pkt 1 ustawy o samorządzie gminnym wskazuje, że rada gminy ze swojego grona może powołać stałe i doraźne komisje do określonych zadań, ustalając przedmiot działania oraz skład osobowy ${ }^{6}$. Ustawodawca przenosi odpowiedzialność dotyczącą powstania takich komisji na organ stanowiący. Rada miejska uchwałą określa wszelkie sprawy dotyczące komisji i zgodnie z ustawą, oczekuje od członków komisji stworzenia planu pracy oraz składania corocznych sprawozdań dotyczących działalności komisji ${ }^{7}$. Zgodnie z artykułem 22 pkt. 1 ustawy „organizację wewnętrzną oraz tryb pracy organów gminy określa statut gminy"8. Wszelkich szczegółów dotyczących pracy organów należy doszukiwać się w uchwałach rady, statutach gminy oraz protokołach z posiedzeń komisji. Na podstawie powyższych materiałów dokonano analizy działalności Komisji Oświaty i Spraw Społecznych w gminie Miłomłyn od początku kadencji w 2014 roku do końca roku 2016, próbując rozważyć zasadność istnienia komisji stałych w tak małych gminach oraz analizując zaangażowanie radnych w pracę na rzecz samorządu z wykorzystaniem takich organów, jakim są właśnie komisje stałe.

\footnotetext{
${ }^{6}$ Ustawa o samorządzie terytorialnym, art. 21 pkt 1 (Dz. U. $1990 \mathrm{nr} 16$ poz. 95).

${ }^{7}$ Ibidem, art. 21 pkt 3.

${ }^{8}$ Ibidem, art. 22 pkt 1.
} 
Franciszek Brzozowski - Prace komisji stałych rad miejskich...

\section{Kształtowanie się władzy - wybory samorządowe 2014}

Miłomłyn to małe miasteczko, położone około 12 kilometrów na północny zachód od Ostródy. Gmina, w 2015 roku, liczyła 5042 mieszkańców ${ }^{9}$, co sytuuje ją wśród jednej z kilkuset mniejszych gmin miejsko-wiejskich w Polsce. Mimo bardzo bogatej historii (miasto otrzymało prawa miejskie już 1335 roku) gmina nie wyróżnia się dużą efektywnością i aktywnością spośród innych gmin w powiecie ostródzkim. W wyborach samorządowych w roku 2014 pojawiło się dwóch kandydatów na stanowisko burmistrza, którzy wystawili swoich kandydatów na radnych w każdym z 15 jednomandatowych okręgów. W wyniku wyborów, które odbyły się 16 listopada 2014 roku Burmistrzem Miasta i Gminy Miłomłyn został Stanisław Siwkowski, wieloletni samorządowiec, dla którego było to już drugie z rzędu zwycięstwo w wyborach do organu wykonawczego gminy. Niestety, kandydaci na radnych, którzy ubiegali się o mandat z Komitetu Wyborczego Wyborców Stanisława Siwkowskiego przekonali do siebie wyborców tylko w 4 okręgach. Natomiast siedem mandatów uzyskali członkowie Komitetu Wyborczego Wyborców Pawła Jaskółowskiego. Co istotne, na 15 członków rady, aż 10 osób to osoby, które pierwszy raz pojawiły się w organach samorządowych, co w dużej mierze dawało nadzieję na inne spojrzenie na sprawy nurtujące gminę Miłomłyn ${ }^{10}$.

Tabela 1. Skład rady miejskiej od 2014 roku

\begin{tabular}{|c|c|}
\hline Imię i nazwisko & Komitet wyborczy \\
\hline Franciszek Brzozowski & KWW Pawła Jaskółowskiego \\
\hline Radosław Gross & KWW Pawła Jaskółowskiego \\
\hline Marek Grzęda & KWW Pawła Jaskółowskiego \\
\hline Zdzisława Milkowska & KWW Pawła Jaskółowskiego \\
\hline Wiesław Lisek & KWW Pawła Jaskółowskiego \\
\hline Grzegorz Walaszczyk & KWW Pawła Jaskółowskiego \\
\hline
\end{tabular}

${ }^{9}$ http://olsztyn.stat.gov.pl/vademecum/vademecum_warminsko-mazurskie/portrety_gmin/ostrodzki/milomlyn.pdf [dostęp: 10-08-2017 r.].

${ }_{10}$ http://www.milomlyn24.pl/index.php/aktualnosci/nasze-miasto/item/82-wielkie -przetasowanie-w-radzie-miejskiej [dostęp: 10-08-2017 r.]. 


\begin{tabular}{|c|c|}
\hline Grzegorz Żmijewski & KWW Pawła Jaskółowskiego \\
\hline Kazimierz Czarnecki & KWW Stanisława Siwkowskiego \\
\hline Nadzieja Jakubczyk & KWW Stanisława Siwkowskiego \\
\hline Krzysztof Kiljański & KWW Stanisława Siwkowskiego \\
\hline Mirosław Ruczyński & KWW Stanisława Siwkowskiego \\
\hline Joanna Dzika & KWW Rozwoju Liwy \\
\hline Joanna Karabinowska & KWW Rozwoju Liwy \\
\hline Alina Król & KWW Aliny Król \\
\hline Andrzej Krzykowski & KWW Andrzeja Krzykowskiego \\
\hline
\end{tabular}

Źródło: opracowanie własne na podstawie http://samorzad2014.pkw.gov.pl/359_ Rady_gmin/0/281507 [dostęp: 10-08-2017 r.].

Po ukonstytuowaniu się władz samorządowych, wybraniu przewodniczącego oraz wiceprzewodniczącego rady przyszła kolej na podjęcie decyzji dotyczącej ustanowienia komisji stałych. Co ciekawe, statut gminy Miłomłyn nie pozostawia wyboru radnym co do utworzenia i nazwania komisji stałych, i w rozdziale IV § 16 pkt. 1 wskazuje, że „rada powołuje następujące komisje:

1. Rewizyjną;

2. Budżetu i Finansów;

3. Rozwoju Gospodarczego, Przedsiębiorczości, Promocji, Rolnictwa i Ochrony Środowiska;

4. Oświaty, Kultury, Zdrowia, Bezpieczeństwa, Spraw Socjalnych, Sportu i Turystyki"11.

Jednak w czasie trwania kadencji dokonano zmiany statutu, wraz ze zmianą nazw dwóch ostatnich komisji stałych na: Komisję Gospodarki i Ochrony Środowiska oraz Komisję Oświaty i Spraw Społecznych ${ }^{12}$. „Statut służy swobodnemu, dostosowanemu do specyfiki miejscowej, kształtowaniu struktur samorządowych i zasad funkcjonowania jego organów"13. Samorządowcy z Miłomłyna, w tym akcie prawa miejscowego, poświecili oddzielny podrozdział dotyczący komisji stałych, jed-

\footnotetext{
${ }^{11}$ Statut Gminy Miłomłyn, rozdział IV § 16 pkt 1.

${ }^{12}$ Uchwała Nr XVIII/102/2016 z dnia 27 stycznia 2016 w sprawie: zmiany Statutu Gminy Miłomłyn

${ }^{13}$ M. Chmaj (red.), Status prawny rady gminy, Warszawa 2012, s. 176.
} 
Franciszek Brzozowski - Prace komisji stałych rad miejskich...

nakże prócz powtórzenia głównych konkluzji z ustawy o samorządzie terytorialnym nie wnoszą one nic nowego. Wskazują przede wszystkim na możliwość wspólnych posiedzeń kilku komisji oraz współpracy z komisjami innych gmin, a także innymi podmiotami, które miałaby pomóc w realizacji zadań, jakie podejmuje się dana komisja. Za pracę komisji odpowiada przewodniczący, który ma za zadanie co najmniej raz w roku złożyć sprawozdanie z działalności komisji, prowadzi on również obrady i ustala ich porządek. Zasadnicze kwestie dotyczące funkcjonowania komisji sformułowano w $§ 71$ pkt 3, który stanowi: „Komisje uchwalą opinie oraz wnioski i przekazują je Radzie"14. Z pewnością zamysł organu stanowiącego był słuszny - komisje w mniejszym gronie, mogące również korzystać z pomocy innych podmiotów, są w stanie sformułować bardziej przemyślane wnioski i opinie, niż podczas posiedzeń rady. Bardzo cenne uwagi do obligatoryjnych norm, jakie powinny znaleźć się w statucie - i dotyczyć komisji stałych - przedstawia Marek Chmaj. Według niego statut powinien wskazywać szczegółową listę komisji stałych oraz ich zadania, liczebność komisji, rozbudowane zasady wyboru członków komisji, tryb wyboru komisji, tryb głosowania oraz organizację wewnętrzną komisji ${ }^{15}$. W statucie Miasta i Gminy Miłomłyn nie doszukamy się jednak zasad wyboru członków i trybu wyboru komisji ${ }^{16}$. Co ciekawe, w statucie mogą się również pojawić zapisy, które uzależniają dopuszczalność projektów uchwał pod głosowanie od wcześniejszego ich zaopiniowania przez właściwą komisję. Brak opinii może spowodować nieważność uchwały. Jak zwraca uwagę Dolnicki, takie zapisy mogę się pojawić zwłaszcza wtedy, gdy komisje stałe powołuje się na początku kadencji ${ }^{17}$. Należy uznać, że statut miasta i gminy Miłomłyn zapewnia podstawową wykładnię prawną dla wszystkich organów i osób zainteresowanych samorządnością, ale w niektórych aspektach powinien być rozszerzony - przede wszystkim winien wskazywać dokładne zadania komisji stałych oraz sam tryb powoływania komisji i jej członków.

\footnotetext{
${ }^{14}$ Statut Gminy Miłomłyn, rozdział V $§ 71$ pkt. 3.

${ }^{15}$ Status prawny rady gminy, op. cit., s. 176.

${ }^{16}$ Statut Gminy Miłomłyn, rozdział V § 69-§75.

${ }^{17}$ B. Dolnicki, Samorząd terytorialny, Warszawa 2016, s. 82.
} 
W związku z tym, że radni byli zobowiązani do ustanowienia komisji stałych, doszło do podjęcia uchwały $w$ sprawie ustalenia przedmiotu działania oraz powołania składu osobowego Komisji Rady Miejskiej, wskazującej w § 1 pkt 1 skład osobowy Komisji Oświaty, Kultury, Zdrowia, Bezpieczeństwa, Spraw Socjalnych, Sportu i Turystyki, który wyglądał następująco: Franciszek Brzozowski, Radosław Gross, Andrzej Krzykowski, Mirosław Ruczyński, Grzegorz Walaszczyk ${ }^{18}$. Osobliwym wydaje się fakt, że mimo tytułu, uchwała nie zawierała w sobie żadnych informacji dotyczących przedmiotu działania komisji, a informowała tylko o składzie osobowym komisji. W skład pięcioosobowej komisji weszło trzech nauczycieli, w tym nauczyciel akademicki, co czyniło ją kompetentną w sprawach, jakie zostały jej powierzone - ten szeroki wachlarz zagadnień wywnioskować można tylko i wyłącznie z nazwy komisji, ponieważ przedmiot czy zakres działania nie został nigdy podany. Można doszukiwać się tutaj także nie wypełnienia ustawowego obowiązku wskazania zadań i przedmiotu działania komisji, narzuconego w artykule 21, pkt 1 ustawy o samorządzie gminnym ${ }^{19}$. Chyba, że uznamy nazwę komisji za element wskazujący przedmiot działania, a jej zadanie tj. opiniowanie uchwał - jako przyjęta norma. Taka interpretacja wydaje się być powszechna, gdyż wojewoda (jako organ nadzoru) nie uchylił żadnej uchwały dotyczącej powołania komisji.

\section{Działalność Komisji Oświaty i Spraw Społecznych.}

Pierwsze posiedzenie Komisji Oświaty, Kultury, Zdrowia, Bezpieczeństwa, Spraw Socjalnych, Sportu i Turystyki odbyło się wspólnie z Komisją Rozwoju Gospodarczego, Przedsiębiorczości, Promocji, Rolnictwa i Ochrony Środowiska 16 grudnia 2014 roku. Porządek przewidywał m. in. wybór przewodniczącego komisji oraz wiceprzewodniczącego. Podczas dyskusji nad wyborem przewodniczącego komisji doszło do bardzo ciekawej dyskusji. Przewodniczący rady Radosław

${ }^{18}$ Uchwała Nr II/5/2014 z dnia 3 grudnia 2014 r. w sprawie ustalenia przedmiotu działania oraz powołania składu osobowego Komisji Rady Miejskiej.

${ }^{19}$ Ustawa o samorządzie terytorialnym, art. 21 pkt 1 (Dz. U. $1990 \mathrm{nr} 16$ poz. 95). 
Franciszek Brzozowski - Prace komisji stałych rad miejskich...

Gross na kandydata wskazał Franciszka Brzozowskiego. Natomiast wiceprzewodniczący rady, Andrzej Krzykowski „poinformował, że były konsultacje i dyskusja na ten temat między nim, a dyrektorami szkół. Dyrektorzy są zgodni i pełni obaw co do tego, że pan Franciszek Brzozowski to młoda osoba, spoza kręgu oświaty"20 (Franciszek Brzozowski miał wtedy 22 lata). Ta dość dziwna interwencja dyrektorów szkół oraz wypowiedź Andrzeja Krzykowskiego była z pewnością przykładem pewnej niesamodzielności niektórych radnych przy działaniach samorządowych, tym bardziej, że zarzuty pod adresem kandydata na przewodniczącego (prócz wieku) były zgoła bezpodstawne - Franciszek Brzozowski w momencie kandydowania był uczestnikiem studiów ze specjalnością nauczycielską oraz odbywał już praktykę w szkołach, więc z pewnością sprawy oświatowe były mu bliskie. Poza tym był on czynnym sportowcem, działającym także w sferze kultury, co w dużej mierze łączyło się zakresem pracy komisji. Mimo wszystko kandydatura została przyjęta jednogłośnie, podobnie jak kandydatura Mirosława Ruczyńskiego, jako wiceprzewodniczącego.

Komisja rozpoczęła pracę bardzo energicznie, w dużej mierze ze względu na problemy, jakie wynikły w jednej ze szkół podstawowych na terenie gminy. Przewodniczący zwołał posiedzenie na 23 grudnia 2014 roku w celu zapoznania się z sytuacją (domniemaną próbą samobójczą jednego z uczniów) oraz ewentualnego udzielania pomocy, w rozwiązaniu problemów organowi prowadzącemu ${ }^{21}$. Co znamienne, było to pierwsze i zarazem ostatnie samodzielne posiedzenie komisji przez cały omawiany okres. Wszystkie następne posiedzenia odbywały się wspólnie z Komisją Rozwoju Gospodarczego, Przedsiębiorczości, Promocji, Rolnictwa i Ochrony Środowiska. Jest to praktyka często spotykana w samorządzie. Komisje wspólnie opiniują projekty uchwał, a każda z nich wpisuje w porządek obrad jeden z wybranych tematów zgodnie z planem pracy. Takie rozwiązanie z jednej strony przyspiesza

${ }^{20}$ Protokół z posiedzenia Komisji Oświaty, Kultury, Zdrowia, Bezpieczeństwa, Spraw Socjalnych, Sportu i Turystyki wspólnie z Komisją Rozwoju Gospodarczego, Przedsiębiorczości, Promocji, Rolnictwa i Ochrony Środowiska z 16 grudnia 2014 r., sygn. $1 / 2014$.

${ }^{21}$ Protokół z posiedzenia Komisji Oświaty... z 23 grudnia 2014 r., sygn. 2/2014. 
proces procedowania, z drugiej strony obniża poziom debaty na temat związany ze specyfiką danej komisji.

Pierwsze obrady w roku 2015 odbyły się 20 stycznia, a ich porządek przewidywał m.in. opracowanie planu pracy komisji. Plany pracy komisji są istotnym elementem porządkującym pracę organu. „Musi obejmować realizację wszystkich ustawowych zadań. Nie jest możliwe skontrolowanie całości wykonywanych zadań przez wszystkie podmioty w ciągu roku”22. Natomiast Henryk Gajoch zauważa, że „najważniejszą kwestią związaną z tworzeniem planu pracy komisji przy społecznym charakterze funkcjonowania organu stanowiącego gminy (...) jest konsekwencja w pełnym i starannym wykonywaniu ujętych w nich zadań, co świadczy o skutecznej realizacji funkcji kontrolnej rady"23. O konsekwencji w realizacji planu pracy niech świadczy fakt, że od wielu lat plany są niemal identyczne. Od nowej kadencji przewodniczący postanowił dodać kilka istotny tematów i stworzono następujący plan:

„Styczeń: Opracowanie planu pracy Komisji na 2015 r.

Luty: Informacja o stanie kultury fizycznej na terenie Gminy Miłomłyn

Marzec: Sprawozdanie z działalności Domu Kultury, Biblioteki Miejskiej i świetlic wiejskich za 2014r. i planowane działania na 2015r.

Kwiecień: Informacja z działalności Miejsko-Gminnego Ośrodka Pomocy Społecznej.

Maj: Informacja o planowanych zadaniach i arkuszach organizacyjnych szkół na rok 2015/2016.

Czerwiec: Informacja o stanie placów zabaw i kąpieliska miejskiego - zapewnienie bezpieczeństwa wakacyjnego dzieci i młodzieży na terenie gminy. Informacja o zamierzeniach Gminy w zakresie letniej akcji wypoczynku dzieci i młodzieży. Informacja na temat funkcjonowania służby zdrowia w Miłomłynie. Lipiec: miesiąc urlopowy.

Sierpień: Ocena przygotowania szkół i punktów przedszkolnych do nowego roku szkolnego - posiedzenie wyjazdowe.

Wrzesień: Informacja o aktualnym stanie bezrobocia w gminie. Sprawozdanie z działalności Domu Kultury, Biblioteki Miejskiej i świetlic wiejskich w okresie wakacji.

Październik: Informacja o stanie realizacji zadań oświatowych w rok. szk. 2014/2015 wraz z wynikami sprawdzianów i egzaminu gimnazjalnego.

${ }^{22}$ Status prawny rady gminy..., op. cit., s. 80.

${ }^{23}$ H. Gajoch, Plan pracy komisji, „Wspólnota” nr 8, Warszawa 2008, s. 5. 
Franciszek Brzozowski - Prace komisji stałych rad miejskich...

Listopad: Analiza projektu budżetu Gminy na rok 2016 z uwzględnieniem wydatków na oświatę, służbę zdrowia, kulturę, bezpieczeństwo, sprawy socjalne, sport i turystykę.

Grudzień: Opiniowanie budżetu Miasta i Gminy Miłomłyn. Opracowanie planu pracy Komisji na 2016r."24

Należy zauważyć, że plan przyjęty w 2016 roku był identyczny ${ }^{25}$, jak ten z 2015 roku, co jednoznacznie wskazuje, że członkowie komisji nie dostrzegali innych problemów czy zagadnień, które warto poruszyć.

Na tym samym posiedzeniu, na którym pozytywnie zaopiniowano plan pracy komisji, odbyła się również dyskusja na temat budżetu. Projekt zakładał przeznaczenie środków budżetowych na rzecz spółki komunalnej, której właścicielem jest gmina. Rozmawiano również o zwiększeniu wydatków na wynagrodzenia pracowników urzędu gminy ${ }^{26}$. Przy dalszych punktach dyskusji nie było, uwag radnych również, więc budżet został pozytywnie zaopiniowany (przy jednym głosie przeciw). W związku z tym, że porządek obrad kolejnej sesji przewidywał przyjęcie uchwały w sprawie powołania doraźnej Komisji Statutowej, członkowie komisji postanowili spośród swojego grona wskazać Franciszka Brzozowskiego, jako kandydata na jednego z członków Komisji Statutowej ${ }^{27}$. Już pierwsze posiedzenia wskazywały, że mimo przewagi radnych z komitetu kontrkandydata na burmistrza, doszło do zmiany układu sił i niemal jednogłośnej akceptacji projektów władzy wykonawczej. Ta praktyka będzie widoczna również w następnych posiedzeniach i nie ulegnie zmianie przez cały omawiany okres.

W dniu 24 lutego odbyło się kolejne posiedzenie, a tematem (zgodnie z planem pracy) było wysłuchanie informacji o stanie kultury fizycznej na terenie Gminy Miłomłyn. Po przedstawieniu informacji przez nauczycieli wychowania fizycznego oraz Sekretarza Miasta

\footnotetext{
${ }^{24}$ Plan pracy Komisji Oświaty, Kultury, Zdrowia, Bezpieczeństwa, Spraw Socjalnych, Sportu i Turystyki, załącznik Nr 2 do uchwały Nr IV/20/2015 z dnia 21 stycznia 2015 r. w sprawie zatwierdzenia planów pracy komisji Rady Miejskiej na 2015 rok.

${ }^{25}$ Plan pracy Komisji Oświaty, Kultury, Zdrowia, Bezpieczeństwa, Spraw Socjalnych, Sportu i Turystyki, załącznik Nr 2 do uchwały Nr XVIII/200/2016 z dnia 27 stycznia 2016 r. w sprawie zatwierdzenia planów pracy komisji Rady Miejskie na 2016 rok.

${ }^{26}$ Protokół z posiedzenia Komisji Oświaty..., sygn. 3/2015, k. 3-7.

${ }^{27}$ Ibidem, k. 10.
} 
i Gminy Miłomłyn Ryszarda Portkę, rozgorzała dyskusja na temat poprawy sytuacji w zakresie kultury fizycznej - zwłaszcza w powstawaniu nowych inicjatyw w tym obszarze. Radny Franciszek Brzozowski wskazał na niewykorzystywanie wszystkich środków, aby dotrzeć do mieszkańców, a zwłaszcza tzw. nowych mediów i opieranie się wyłącznie na bezpośrednim informowaniu stałych uczestników zawodów. Wskazał również, że „organizacja imprezy to nie tylko wpływy do budżetu miasta, ale także promocja miasta. Firmy organizujące imprezy szukają takich małych miast, bo wtedy np. nie ma problemu z zamknięciem dróg"28.

Dyskusja nie przyniosła jednak żadnych wniosków i nie zmieniła podejścia organów wykonawczych do organizacji nowych, bardziej masowych imprez sportowych. Do tematu jednak wrócono, w grudniu 2015 roku. Do tego czasu (od lutego) komisja nie przejawiała żadnego zainteresowania poruszaną tematyką, większych dyskusji nie odnotowano, a projekty uchwał był pozytywnie opiniowane bez żadnych uwag. 15 grudnia, przewodniczący komisji, poruszył sprawę informowania mieszkańców gminy o organizowanych imprezach sportowych i kulturalnych:

\begin{abstract}
„Stwierdził, że duża część mieszkańców nie czyta ogłoszeń zamieszczonych na stronie internetowej gminy oraz na tablicach ogłoszeń. W związku z tym zaproponował rozważenie możliwości zaplanowania środków na wydanie, uzgodnionej z instytucjami kultury, jednej ulotki dla mieszkańców, informującej o tym, jakie imprezy kulturalno-sportowe są organizowane na terenie gminy"29.
\end{abstract}

Sekretarz nie ustosunkował się do tej propozycji, natomiast Radosław Gross zaproponował powstanie Centrum Kultury, „bądź Centrum Kultury i Sportu, które powinno mieć stronę internetową, gdzie będą zamieszczane wszelkie informacje o wszystkich organizowanych imprezach sportowych i kulturalnych" ${ }^{30}$. Trzeba przyznać, że propozycje były bardzo poważne, ale niestety nie spotkały się z entuzjastycznym

\footnotetext{
${ }^{28}$ Protokół z posiedzenia Komisji Oświaty..., sygn. 4/2015, k. 4.

${ }^{29}$ Protokół z posiedzenia Komisji Oświaty..., sygn. 12/2015, k. 7.

${ }^{30}$ Ibidem, k. 8.
} 
Franciszek Brzozowski - Prace komisji stałych rad miejskich...

przyjęciem - do sprawy Centrum Kultury wrócono nieoczekiwanie kilka posiedzeń później. Członkowie komisji, w 2015 roku, wykazali chęć zmiany zastanego porządku w sferach kultury i sportu, jednakże nie wykorzystali możliwości inicjatywy uchwałodawczej, ani nie nalegali na żadne inicjatywy ze strony organu stanowiącego czy wykonawczego. Jedną z przyczyn takiej bierności organu mogła być słaba znajomość prerogatyw jakie posiada radny, komisja czy rada. Było to bardzo widoczne przy okazji innych dyskusji roku następnego.

Pierwsze posiedzenie w 2016 roku odbyło się 26 stycznia i przyniosło ono próbę poszukania rozwiązań dotyczących zniwelowania problemu alkoholizmu na terenie gminy. Po wysłuchaniu informacji Gminnej Komisji Rozwiązywania Problemów Alkoholowych radny Radosław Gross zaproponował zmniejszenie punktów sprzedaży alkoholu (to organ stanowiący określa liczbę takich punktów za pomocą uchwały). Na terenie gminy funkcjonuje 28 takich punktów, w tym $9 \mathrm{z}$ nich to punkty gastronomiczne. Nikt z członków komisji nie zabrał głosu w tej sprawie i bez żadnych konkluzji zakończono posiedzenie ${ }^{31}$. Po raz kolejny można zauważyć chęć zmian, jednak bierność i niezrozumienie wagi podnoszonych problemów prowadzi do bezowocnych posiedzeń.

Wyróżniające się na tle innych posiedzeń, były wspólne obrady wszystkich komisji dotyczące projektu połączenia Miejsko-Gminnej Biblioteki Publicznej oraz Miejsko-Gminnego Ośrodka Kultury w jedną instytucje - było to pokłosie omawianych kilka sesji wcześniej koncepcji dotyczących aktywizacji społeczeństwa. Otwierając dyskusję, przewodniczący rady, Radosław Gross:

„stwierdził, że przymiarka Rady dotycząca połączenia Miejsko-Gminnego Ośrodka Kultury i Miejsko-Gminnej Biblioteki Publicznej w Miłomłynie trwa od ponad pół roku. W tym celu burmistrz i radny Marek Grzęda złożyli wizytę w Dąbrównie, gdzie doszło do takiego połączenia i na miejscu zorientowali się jak ta sprawa wygląda. Następnie został przygotowany projekt uchwały intencyjnej nie przesądzającej o uchwale, która ma otworzyć możliwość połączenia tych dwóch instytucji”32

\footnotetext{
${ }^{31}$ Protokół z posiedzenia Komisji Oświaty..., sygn. 13/2016.

${ }^{32}$ Protokół ze wspólnego posiedzenia komisji Rady Miejskiej, sygn. 15/2016, k. 2.
} 
Trzeba przyznać, że te słowa wprowadziły w konsternacje niektórych radnych, ale przede wszystkim dyrektorów placówek, którzy nic nie wiedzieli o wizycie w Dąbrównie oraz, co niezmiernie ważne - nie zostali zaproszeni na komisje. Przyszli, ponieważ otrzymali informacje, że porządek obrad przewiduje dyskusje na ten temat. W obronę pozostawienia instytucji jako pierwszy stanął radny Ruczyński, który zauważył, że ,jeżeli nasza gmina nie ma zamiaru przenoszenia biblioteki do ośrodka kultury [te dwie instytucje znajdują się w dwóch różnych budynkach - F.B], to uważa, że należy dać tej sprawie spokój, gdyż każda z tych instytucji ma swoją specyfikę" ${ }^{33}$. Zwolennikiem połączenia wydawał się być radny Marek Grzęda, który

„stwierdził, że celem połączenia instytucji kultury nie jest zmniejszenia zatrudnienia w tych instytucjach oraz zmniejszenie wynagrodzenia, o czym mówił już kilkakrotnie. Uważa, że połączenie tych dwóch instytucji jest zasadne, ponieważ działają blisko siebie w obrębie kultury, gdzie w każdej z nich jest jeden dyrektor i jeden pracownik, jest odrębnie prowadzona księgowość, co stwarza koszty. Jego celem było to, by ewentualnie zaoszczędzone jakiekolwiek środki w wyniku połączenia tych placówek pozostawić do dyspozycji nowej instytucji”"34.

Do dyskusji, w której doszukiwać się można było argumentów bardziej ad personam aniżeli ad rem włączyła się dyrektor biblioteki publicznej - Teresa Godek, która na początku wskazała, że „czuje się źle, dlatego, że nie została zaproszona na posiedzenie"35. Następnie przedstawiła szereg argumentów merytorycznych, porównując działalności gminnej biblioteki z innymi ośrodkami w województwie. Przedstawiła również ciekawy wniosek: „Aby ulepszyć funkcjonowanie instytucji nie trzeba ich łączyć. Wystarczy spotkać się z dyrektorami szkół, instytucji, stowarzyszeń i opracować plan działania"36. Po Pani Godek

„Dyrektor Miejsko-Gminnego Ośrodka Kultury Zbigniew Rochowic zwrócił uwagę, że szkoda, iż nie zaproszono ich na wyjazdowy rekonesans do nowo powstałego Centrum Kultury w Dąbrównie. Był tam później i rozmawiał

\footnotetext{
${ }^{33}$ Ibidem, k. 3

${ }^{34}$ Ibidem.

${ }^{35}$ Ibidem.

${ }^{36}$ Ibidem.
} 
Franciszek Brzozowski - Prace komisji stałych rad miejskich...

z dyrektorem tego centrum. Uzyskał od niego informację, że tamtejsze centrum kultury otrzymuje z budżetu gminy na realizacje zadań 550 tys." ${ }^{37}$

i

„przypomniał, że w ubiegłym roku otrzymał na działalność ośrodka kultury w Miłomłynie 145 tys. (...) Po odjęciu wszystkich wydatków związanych z utrzymaniem budynku, wynagrodzeniami i ich pochodnymi z budżetu, jaki posiada ośrodek kultury na działalność kulturalną zostaje 1000 zł. Gdybanie to, że MGOK był partnerem w projektach, to byłoby ciężko"38.

Trzeba przyznać, że słowa te bardzo dobrze oddały sens tej dyskusji - przy zmarginalizowaniu wydatków na kulturę (według przyjętego budżetu na rok 2016 dotacja podmiotowa na M-GOK w Miłomłynie wynosiła 170000 zł z czego około 2-3\% poświęcone jest na zapewnienie stałej oferty kulturalnej, a 15\% na jednorazowe imprezy gminne - dożynki czy Dni Miłomłyna. Reszta kwoty spożytkowane jest na bieżące utrzymanie domu kultury ${ }^{39}$ ) oczekiwano, że połączenie dwóch instytucji i stworzenie jednej przyniesie nagły wzrost aktywności kulturalnej. Analizując powyższe należy zauważyć głębokie problemy jakie nękają sferę kultury w Miłomłynie, a nie są kompletnie poruszane w czasie dyskusji. Sposób zarządzania, łożone środki oraz sposób dysponowania zdają się być najważniejszymi problemami gminy w tej sferze - jednak od wielu problemy te nie są publicznie poruszane.

Kolejne elementy dyskusji wskazywały na niezbyt przyjazne stosunki dyrektora ośrodka z organem wykonawczym. „Skarbnik Miasta i Gminy Sylwia Bartoszuk zapytała dyrektora MGOK, Pana Zbigniewa Rochowicza czy składał wniosek do gminy, że chce zwiększenia dotacji na przeprowadzenie jakiejś inicjatywy kulturalnej na terenie gminy? Stwierdziła, że do niej nie dotarła taka informacja" ${ }^{40}$. Dyrektor wskazywał, że „złożył projekt budżetu na funkcjonowanie ośrodka kultury na 2016 rok, który opiewał na ponad 200 tys., a otrzymał 170 tys." ${ }^{41}$.

\footnotetext{
${ }^{37}$ Ibidem.

${ }^{38}$ Ibidem, k.4.

${ }^{39}$ Uchwała Nr XVI/89/2015 z dnia 16 grudnia 2015 r. w sprawie uchwalenia budżetu Miasta i Gminy Miłomłyn na 2016 r.

${ }^{40}$ Protokół ze wspólnego posiedzenia komisji Rady Miejskiej, sygn. 15/2016, k. 4.

${ }^{41}$ Ibidem.
} 
Poziom rozmowy pomiędzy przedstawicielami instytucji publicznych oraz samorządu zaczął znacząco odbiegać od powagi, jaką powinny cechować się posiedzenia organów samorządowych. Wzajemna znajomość w tak małej społeczności oraz niskie nakłady na kulturę również wpływają na poziom debaty oraz zachowanie jej uczestników. Do dyskusji włączył się radny Franciszek Brzozowski, który „poinformował, że w wakacje ubiegłego roku na swoje własne potrzeby przeprowadził wśród młodzieży ankietę dotyczącą ich zainteresowań. (...) Ankieta ta wykazała różnorodne zainteresowania”. Stwierdził jednak, że „gmina Miłomłyn „śpi” kulturalnie, tu się niewiele dzieje, nie dlatego że jest mało pieniędzy". Uważa, że za nim odgórnie przekaże się pieniądze należy

„zrobić ankietę wśród dzieci i młodzieży, pójść do młodych z inicjatywą. Jeżeli Burmistrzowi nie podoba się praca dyrektorów instytucji kultury z terenu gminy, to jest organem wykonawczym i może wyciągnąć w stosunku do nich konsekwencje, a radni mogą jedynie podjąć decyzję, że zamiast 1000 zł przekażą 20000 zł na działalność kulturalną - i niech pan dyrektor się wykaże. Jeżeli środki będą źle wykorzystane to Pan Burmistrz może rozwiązać z nimi umowę"42.

Po wypowiedzi radnego, niejako podsumowując dyskusję, przewodniczący rady przedstawił wniosek, aby

„powołać zespół z udziałem członków Komisji Oświaty i Spraw Społecznych, osoby z urzędu wyznaczonej przez burmistrza, dyrektora Miejsko-Gminnego Ośrodka Kultury i Miejsko-Gminnej Biblioteki Publicznej w celu wypracowania wspólnego programu, który trwałby rok. Byłoby spisane sprawozdanie, z którego można rozliczyć po roku. Byłaby wtedy szansa na to, żeby weryfikować" ${ }^{\prime 3}$.

Na taki wniosek radny Brzozowski wskazał, „aby udział w tym zespole wzięli również pedagodzy, dyrektorzy szkół. Uważa, że zespół ten powinien przeprowadzić ankietę wśród młodzieży i wtedy opracować program"44. Burmistrz pozytywnie ustosunkował się do powstania takiego zespołu/komisji. A ostatnie zdanie w tym punkcie posiedze-

\footnotetext{
${ }^{42}$ Ibidem.

${ }^{43}$ Ibidem, k.5.

${ }^{44}$ Ibidem.
} 
Franciszek Brzozowski - Prace komisji stałych rad miejskich...

nia wskazuje, że takowa komisja powstanie: „Odbyła się dyskusja nad połączeniem instytucji kultury i wynikiem tej dyskusji jest powołanie komisji, a nie ich połączenie [oczywiście mowa o instytucjach - F.B]"45. Co ciekawe komisja takowa nigdy nie powstała, a temat - tak jak poprzednie - zniknął z porządków obrad czy dyskusji. Wnioski, jakie można wysnuć z powyższych faktów, są przygnębiające i rzutują na ocenę działań samorządowców. Próba zmian w obrębie kultury - jakże ważnej dziedzinie - została sprowadzona do słownych przepychanek i przyjęcia wniosków, które nigdy nie zostały wprowadzone w życie. Wydawać się może, że wizja samorządności staje się raczej iluzją, aniżeli stanem faktycznym. A personalne ataki oraz błahe problemy i rozwiązania ad interim biorą górę nad ważnymi i głębokimi uchybienia w sferze kultury.

Do końca 2016 roku obyło się jeszcze 6 posiedzeń na których nie podjęto żadnych istotnych wniosków, a kolejna burzliwa dyskusja dotycząca sytuacji w Ośrodku Zdrowia, nie przyniosła nic prócz indywidualnego wypowiadania własnych trosk przez radnych, nie poszukując żadnych prospołecznych rozwiązań ${ }^{46}$.

\section{Podsumowanie}

Podsumowując działalność Komisji Oświaty i Spraw Społecznych Rady Miejskiej w Miłomłynie należy zwrócić uwagę na prerogatywy, jakie posiadają komisje stałe. Ustawodawca nie przewidział żadnych konkretnych zadań, cedując odpowiedzialność na jednostkę samorządu terytorialnego. I to rada miejska w Miłomłynie podjęła decyzję o umieszczeniu w statucie konkretnych zapisów dotyczących komisji stałych, przede wszystkim wskazując na liczbę komisji oraz ich nazewnictwo. W żadnych dokumentach nie widnieją zapisy dotyczące dokładnych zadań czy obszaru zainteresowania komisji. 0 tematyce, jaka jest poruszana na posiedzenia decydują członkowie komisji, formułując roczny plan pracy, który musi zostać zaakceptowany przez

\footnotetext{
45 Ibidem.

${ }^{46}$ Protokół z posiedzenia Komisji Oświaty..., sygn. 18/2016.
} 
radę. Trzeba jednak zwrócić uwagę, że plany pracy są niemal rok w rok takie same, co wskazuje raczej na ignorancję, niż na głębokie zainteresowanie problemami miasta i gminy. Bodaj najważniejsze konkluzje można wysnuć podczas analizy efektów pracy członków komisji, a raczej ich braku. Członkowie komisji, mimo statutowego zobowiązania, nie formułują żadnych wniosków ani opinii - tym samym nie spełniają podstawowego celu, w jakim wszystkie komisji stałe są powoływane. Skoro nie formułowane są wnioski, nie są konieczne również szerokie dyskusje, np. wraz z zaproszonymi w tym celu przedstawicielami istotnych instytucji. Przewodniczący komisji (jak to już zostało zwyczajowo przyjęte) nie składa żadnego sprawozdania radzie z działalności komisji, co jest jawnym nieprzestrzeganiem obowiązków statutowych (§74) oraz wskazuje na słabość organu stanowiącego, który odpowiada za przestrzeganie statutu przez swoje organy wewnętrzne. Mimo sformułowanego planu pracy wydaje się, że pełni on rolę fasadową, ponieważ podczas poruszania danych tematów nie są prowadzone żadne dyskusje, a temat wyczerpuje się po wysłuchaniu informacji przedstawiciela organu wykonawczego. Po co więc przyjmować plan z zakładaną tematyką, skoro nie chce się na ten temat rozmawiać? Jest to jeden z paradoksów działalności Komisji Oświaty i Spraw Społecznych, ale jak mniemam również innych komisji stałych w mniejszych gminach miejsko-wiejskich, gdzie ani warunki lokalne, ani budżet, ani kompetencje radnych i ich zaangażowanie nie pomagają w aktywnym samo-rządzeniu.

\section{Bibliografia:}

Bukowski Z., Jędrzejewski T., Rączka P., Ustrój samorządu terytorialnego, Wyd. „Dom Organizatora”, Toruń 2005.

Chmaj M. (red.), Status prawny rady gminy, Wyd. Dyfin, Warszawa 2012.

Dolnicki B., Samorzq̨d terytorialny, Wyd. Lex, Warszawa 2012.

Dolnicki B., Samorząd terytorialny, Wyd. Wolters Kluwer, Warszawa 2016.

Gajoch H., Plan pracy komisji, „Wspólnota” 2008, nr 8.

Izdebski H., Samorząd terytorialny. Podstawy ustroju i działalności, Wyd. Lexi-

sNexis, Warszawa 2009. 
Franciszek Brzozowski - Prace komisji stałych rad miejskich...

Kisiel B. (red.), Prawo terytorialne w Polsce, Wyd. LexisNexis, Warszawa 2006. Kozłowski A. J., Samorząd terytorialny w Polsce, Wyd. Soft Vision, Szczecin 1997.

Nowacka E. J., Polski samorzq̨d terytorialny, Wyd. LexisNexis, Warszawa 2006

Wójcik S., Samorząd terytorialny w Polsce w XX wieku, Wyd. KUL, Lublin 1999. 